\title{
SCIENCE FICTION WRITERS' PREDICTIONS COME TRUE
}

\author{
Olesya Viktorovna Savenko
}

Lecturer, Department of Russian And World Literature, Termez State University, Uzbekistan

\section{ABSTRACT}

The article examines the predictions of the writers who came true; the works of Jules Verne, HG Wells, Mark Twain are considered.

KEYWORDS: - "Characters" of science fiction novels, stunning prophecies, biological weapons, artificial insemination, the arrow-shaped writer, computer programs, the worldwide telephone.

\section{INTRODUCTION}

In many works of science fiction writers, the question of the future of our planet is sharply raised, and each of them offered its own models of the future. What they just didn't compose, what they didn't prophesy. A lot of contemporary phenomena and objects that we consider commonplace were once "characters" of science fiction novels and novellas.

Jules Verne is a techno-romantic who firmly believed in progress, the inexorable logic of the researcher and the iron will of the discoverer. The list of things that Verne "got" into is quite long. The most amazing prophecies of J. Verne were found in his novel Paris in the 20th century, written in 1863 and found by chance by the writer's great-grandson only in 1994 . The novel takes place in 1960 in Paris. The novel describes in detail such things, the invention of which another inhabitant of the 19th century could not even guess: cars drive through the streets, criminals are executed with the help of an electric chair, documents are transmitted by means of a device resembling a modern fax. In the same novel, the author described the prototype of television, as well as the ability to communicate by seeing the interlocutor on the monitor.

No less striking are the predictions of another famous science fiction writer, H.G. Wells. He predicted what became reality many decades later: biological weapons, artificial insemination, the method of introducing nutrients directly into the blood, etc. Observing the flight of birds, he predicted that in the future, high-speed aviation will move to a swept wing - aircraft designers came to this conclusion only twenty years later.

In the novel War of the Worlds, published in 1898, H. Wells describes the action of a heat beam, which is similar to a modern laser: "Then slowly the hissing passed into a humming, into a long, loud, droning noise. Slowly a humped shape rose out of the pit, and 
CURRENT RESEARCH JOURNAL OF PHILOLOGICAL SCIENCES 2(8): 36-38,

May 2021 DOI: https://doi.org/10.37547/philological-crjps-02-08-09

ISSN 2767-3758

(C)2021 Master Journals

Crossref doi) 81 Google

Accepted26 ${ }^{\text {th }}$ August, 2021 \& Published $31^{\text {th }}$ August, 2021

the ghost of a beam of light seemed to flicker out from it.

Forthwith flashes of actual flame, a bright glare leaping from one to another, sprang from the scattered group of men. It was as if some invisible jet impinged upon them and flashed into white flame. It was as if each man were suddenly and momentarily turned to fire.

Then, by the light of their own destruction, I saw them staggering and falling, and their supporters turning to run.

I stood staring, not as yet realising that this was death leaping from man to man in that little distant crowd. All I felt was that it was something very strange. An almost noiseless and blinding flash of light, and a man fell headlong and lay still; and as the unseen shaft of heat passed over them, pine trees burst into fire, and every dry furze bush became with one dull thud a mass of flames. And far away towards Knaphill I saw the flashes of trees and hedges and wooden buildings suddenly set alight.

It was sweeping round swiftly and steadily, this flaming death, this invisible, inevitable sword of heat. I perceived it coming towards me by the flashing bushes it touched, and was too astounded and stupefied to stir. I heard the crackle of fire in the sand pits and the sudden squeal of a horse that was as suddenly stilled. Then it was as if an invisible yet intensely heated finger were drawn through the heather between me and the Martians, and all along a curving line beyond the sand pits the dark ground smoked and crackled. Something fell with a crash far away to the left where the road from Woking station opens out on the common. Forth-with the hissing and humming ceased, and the black, dome-like object sank slowly out of sight into the pit».

In his novel When the Sleeper Wakes up, Wells describes a device with which one can choose a style for a suit: the screen of the cinema, a human figure in white moved. The tailor chose a sample of bluish silk. "That seems to me to be exactly what you need," he said.

A fat man came up to them and looked over Graham's shoulder.

"Please hurry up: time is precious," he said.

"Trust me," said the tailor. - My car will be brought in now .... Well, what do you think of this, sir? - he turned to Graham.

- What kind of device do you have? - asked, in turn, a man of the nineteenth century.

- You see, there were fashion magazines in your days. Now this very little thing has replaced them. A preconventional invention. Look.

He pressed the button again, and the same figure popped up on the dial of the device, but in a new outfit of a wider cut. Click, click - and again the little man changed his costume ...".

For Wells' contemporaries, this was fantastic; in the modern world, we can use computer programs to choose a style for a suit or hairstyle.

American Mark Twain can hardly be called a science fiction writer in the classical sense of the word. Nevertheless, he created several fantastic works, and among them is the story "From the London Times" for 1904 ", written by him in 1898.

The invention, which has all the features of the modern Internet, the writer called the "teleelectroscope", or the worldwide telephone. The hero of the story, Clayton, gets it at his disposal, and this is what he can do: "The device was taken out and connected to the international telephone network. Now Clayton called all over the world day and night, looked at life there, watched various outlandish sights, talked to people, and thanks to this wonderful invention it began to seem to him that he had grown wings, and he could fly wherever he wanted. " 
CURRENT RESEARCH JOURNAL OF PHILOLOGICAL SCIENCES 2(8): 36-38,

May 2021 DOI: https://doi.org/10.37547/philological-crjps-02-08-09

ISSN 2767-3758

(C)2021 Master Journals

crossref do) 8 il Google

Accepted26 ${ }^{\text {th }}$ August, 2021 \& Published 31 ${ }^{\text {th }}$ August, 2021

\section{REFERENCES}

1. Meshcheryakova M. What is fantasy? - M., 2001.

2. Novikova N. A. The image of the future and its formation in society. -

http://www.socialphenomena.org/article/novi kova_essay2013/

3. Ryzhov A. S. Literary prophets. They predicted the future. - M .: Eskimo, 2007.

4. Verne J. Paris in the twentieth century. - M .: International relations, 1995.

5. Wells G. War of the Worlds. - M .: AST, 2014.

6. Wells G. When the sleeper wakes up. http://az.lib.ru/u/uells_g_d/text_1899_the_slee per_awakes.shtml

7. Twain M. From The London Times, 1904. http://rulibs.com/ru_zar/prose_classic/tven/1a /j2.html 